
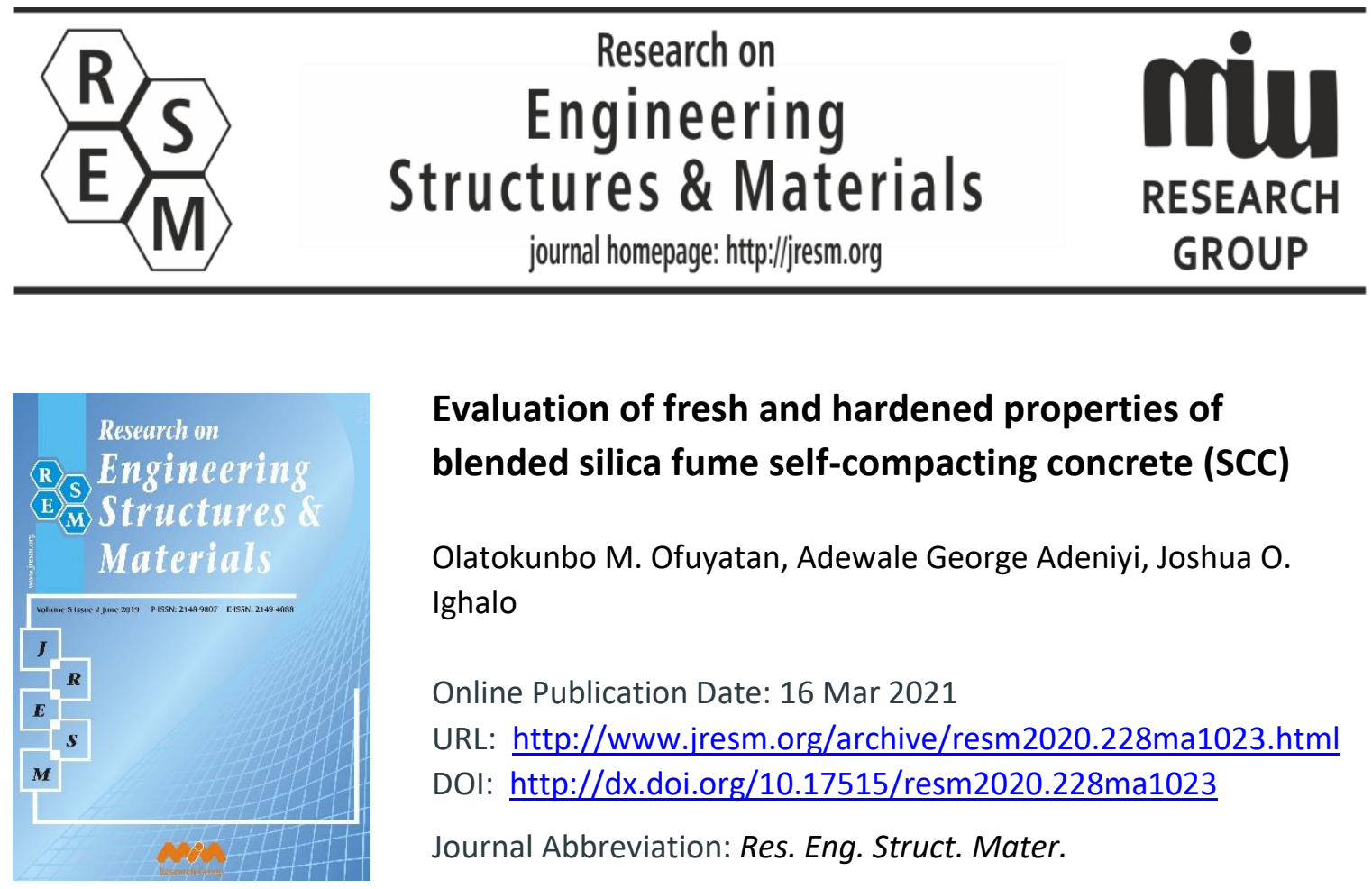

\title{
Evaluation of fresh and hardened properties of blended silica fume self-compacting concrete (SCC)
}

Olatokunbo M. Ofuyatan, Adewale George Adeniyi, Joshua O. Ighalo

Online Publication Date: 16 Mar 2021

URL: http://www.jresm.org/archive/resm2020.228ma1023.html

DOI: http://dx.doi.org/10.17515/resm2020.228ma1023

Journal Abbreviation: Res. Eng. Struct. Mater.

\section{To cite this article}

Ofuyatan OM, Adeniyi AG, Ighalo JO. Evaluation of fresh and hardened properties of blended silica fume self-compacting concrete (SCC). Res. Eng. Struct. Mater., 2021; 7(2): 211-223.

\section{Disclaimer}

All the opinions and statements expressed in the papers are on the responsibility of author(s) and are not to be regarded as those of the journal of Research on Engineering Structures and Materials (RESM) organization or related parties. The publishers make no warranty, explicit or implied, or make any representation with respect to the contents of any article will be complete or accurate or up to date. The accuracy of any instructions, equations, or other information should be independently verified. The publisher and related parties shall not be liable for any loss, actions, claims, proceedings, demand or costs or damages whatsoever or howsoever caused arising directly or indirectly in connection with use of the information given in the journal or related means.

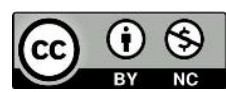

Published articles are freely available to users under the terms of Creative Commons Attribution - NonCommercial 4.0 International Public License, as currently displayed at here (the "CC BY - NC"). 


\title{
Research on Engineering Structures \& Materials \\ journal homepage: http://jresm.org
}

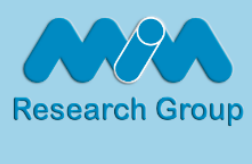

Research Article

\section{Evaluation of fresh and hardened properties of blended silica fume self-compacting concrete (SCC)}

\author{
Olatokunbo M. Ofuyatan1,a*, Adewale George Adeniyi ${ }^{2, b}$, Joshua O. Ighalo 2,c \\ ${ }^{1}$ Department of Civil Engineering, College of Engineering, Covenant University Ota, Lagos, Nigeria \\ ${ }^{2}$ Department of Chemical Engineering, Faculty of Engineering and Technology, University of Ilorin, Ilorin, $P$. \\ M. B. 1515, Nigeria

\begin{tabular}{|c|c|}
\hline Article Info & Abstract \\
\hline $\begin{array}{l}\text { Keywords: } \\
\text { Self Compacting } \\
\text { Concrete; } \\
\text { Silica Fume; } \\
\text { Cement; } \\
\text { Concrete; } \\
\text { Partial Replacement }\end{array}$ & $\begin{array}{l}\text { Recent technologies now investigate the use of materials that can serve as } \\
\text { partial cement replacement and also impact on self-compacting ability in } \\
\text { concrete mixtures. In this study, fresh and hardened properties of self- } \\
\text { compacting concrete containing silica fumes as partial replacement for cement } \\
\text { were evaluated. Cement was replaced by silica fume in the extent of } 15 \%, 25 \% \\
\text { and } 35 \% \text { by volume alongside the control mix }(0 \%) \text {. The flow test, V-funnel test } \\
\text { and L-box test were conducted on the fresh concrete. The compressive } \\
\text { strength, flexural strength, water absorption property and microstructural } \\
\text { properties of the hardened concrete were determined. Utilization of silica fume } \\
\text { as partial cement replacement improved the fresh state properties of the } \\
\text { concrete in the domain of the flow-ability. Higher partial replacement led to } \\
\text { lesser compressive and flexural strength due to weak interfacial transition } \\
\text { zone, the porosity of the mortar during adhesion to the fine and coarse } \\
\text { aggregates. Rapid water absorption was observed after the first day of the } \\
\text { concrete preparation which gradually tailed off with time. }\end{array}$ \\
\hline
\end{tabular}

(C) 2021 MIM Research Group. All rights reserved.

\section{Introduction}

Concrete is the most popularly material used for construction in the world [1]. One of the most important innovations in the construction industry is the development of selfcompacting concrete [2] also known as self-consolidating concrete [3]. Self-compacting concrete (SCC) is a flowing concrete mixture which compacts or is consolidated under its own self weight [4]. This type of concrete can fill form-works without any external mechanical compaction required [1,5]. SSC provides a better process in terms of economics of manpower and finance [6]. SSC allows for the recycling of recycled aggregates in concrete without any significance deterioration of the mechanical properties in the short and long term $[7,8]$.

Cement utilization leads to much release of green-house gases [9]. Partial cement replacement is an important aspect in achieving sustainability in the cement industry [10]. Recent technologies now investigate the use of materials that can serve as partial cement replacement and also impact a self-compacting ability in concrete mixtures [8]. Several studies have utilized materials such as pumice powder [6], nano-silica [11, 12], fly ash [2, 6, 13], metakaolin [14], slag [6, 13], rice husk ash [15] and palm oil fuel ash [16] as partial replacement of cement in self-compacting concrete (SSC).

\footnotetext{
*Corresponding author: adeniyi.ag@unilorin.edu.ng , olatokunbo.ofuyatan@covenantuniversity.edu.ng ${ }^{a}$ http://orcid.org/0000-0001-9052-2758; ${ }^{b}$ http://orcid.org/0000-0001-6615-5361;

chttp://orcid.org/0000-0002-8709-100X;

DOI: http://dx.doi.org/10.17515/resm2020.228ma1023

Res. Eng. Struct. Mat. Vol. 7 Iss. 2 (2021) 211-223
} 
Silica fume, also known as micro silica, is a collection of soot that escapes with exhaust gas during the process of melting industrial silicon and ferrosilicon at high temperature using an industrial electric furnace [17]. Silica fume and superplasticizer are reciprocal materials to produce self-levelling cements with incredible attachment of the crisp blend [18]. Superplasticizers are admixtures for concrete, which are incorporated to reduce the water content in a mix or to direct the setting rate of the strong while holding the spilling properties of a mix. One of the best points of interest of utilizing silica fume in SCC is due to its small size which makes self compaction possible. The expansion of silica smoulder augments the size conveyance of the cementitious particles in cement, permitting progressively effective molecule pressing, densifying the interfacial change zone and changing over $\mathrm{CH}$ into $\mathrm{C}-\mathrm{S}-\mathrm{H}$, therefore expanding quality and toughness.

In recent times, silica fumes have gained popularity as a partial replacement for cement to achieve sustainable building and formwork. Ardalan, Joshaghani [6] utilized silica fume in a blend with pumice in SSC. They observed that the addendum improved the compressive strength and workability of the SSC. Bernal, Reyes [11] observed that a ternary mixture of nano-silica and silica fumes gave the best mechanical properties together (in contrast with the binary blends). Ghoddousi and Saadabadi [14] studied the use of electrical resistivity of SSC to determine the amount of calcium hydroxide. The study investigated SSC containing silica fumes and metakaolin. Leung, Kim [19] studied the moisture absorption properties of SSC obtained using flay ash and silica fumes as partial cement replacement. Moisture absorption decreased with partial replacement but compressive strength was improved. No relationship was observed between moisture absorption and compressive strength. Sasanipour, Aslani [20] observed that silica fumes in SSC (developed with waste concrete aggregates) has less moisture absorption and porosity. In terms of the pore properties, an optimum of 5\% silica fume in SSC was observed by Zarnaghi, Fouroghi-Asl [21].

Although there are much benefits of SSC, it has not yet gained widespread use in Nigeria. The aim of this study is to evaluate the fresh and hardened properties of self-compacting concrete obtained using silica fumes as partial replacement for cement. The flow test, Vfunnel test and L-box test were conducted on the fresh concrete. The compressive strength, flexural strength, water absorption property and microstructural properties of the hardened concrete were determined. Alongside the microstructural analysis the compositional elements of the concrete was investigated using Scanning Electron Microscope with Energy Dispersive Spectroscopy (SEM-EDS).

\section{Methodology}

\subsection{Materials}

The cement type used in carrying out this experiment is Ordinary Portland Cement (OPC); Dangote cement of grade 42.5R, Nigeria. The fine aggregate used was natural sharp river sand obtained from river Ogun, Nigeria. It was free of silt deleterious materials and did not exceed $5 \mathrm{~mm}$ size. Most common type of course aggregates used for construction work is $19 \mathrm{~mm}$ size. Crushed, angular, graded granite having maximum size of $19 \mathrm{~mm}$ was therefore used as coarse aggregate. Conplast SP430 was used in the study. It is a brown chloride free liquid which instantly disperses in water. The properties of the superplasticizer used are given in Table 1 . The other materials used in this study are fine silica fume and water (ASTM C1602 standard). 
Table 1. Properties of Conplast SP430

\begin{tabular}{cc}
\hline Property & Description \\
\hline Appearance & Brown Liquid \\
Specific Gravity & 1.175 @ $30^{\circ} \mathrm{C}$ \\
Chloride Content & Nil BS 5075 \\
Alkaline Content & Less than $50 \mathrm{~g}$. $\mathrm{Na}_{2} \mathrm{O}$ equivalent/liter of admixture \\
\hline
\end{tabular}

\subsection{Concrete mix design}

For the investigation, four mixes of cubes (150 mm X $150 \mathrm{~mm}$ X $150 \mathrm{~mm}$ ) were cast. Cement was replaced by silica fume in the extent of $15 \%, 25 \%$ and $35 \%$ by volume alongside the control mix (0\%). After principal blend outline, the trial blend was planned and evaluated for the initial properties of SCC as indicated by EFNARC [22] rules. The fine aggregate, coarse aggregate, water content ratio and superplasticizer were kept constant for different mixes while cement and silica fume were varied based on gradual replacements. The details of the 4 mix proportions used in the study are presented in Table 2.

Table 2. Mix proportions

\begin{tabular}{ccccc}
\hline Constituents $\left(\mathrm{kg} / \mathrm{m}^{3}\right)$ & Mix 1 & Mix 2 & Mix 3 & Mix 4 \\
\hline Portland Cement $\left(\mathrm{kg} / \mathrm{m}^{3}\right)$ & 417.15 & 375.44 & 333.72 & 292 \\
Fine Aggregates $\left(\mathrm{kg} / \mathrm{m}^{3}\right)$ & 952 & 952 & 952 & 952 \\
Coarse Aggregate $\left(\mathrm{kg} / \mathrm{m}^{3}\right)$ & 653.54 & 653.54 & 653.54 & 653.54 \\
Silica Fume $\left(\mathrm{kg} / \mathrm{m}^{3}\right)$ & 0 & 41.72 & 83.43 & 125.15 \\
Water Cement Ratio $(\%)$ & 0.45 & 0.45 & 0.45 & 0.45 \\
Superplasticizer $\left(\mathrm{kg} / \mathrm{m}^{3}\right)$ & 4.17 & 4.17 & 4.17 & 4.17 \\
\hline
\end{tabular}

\subsection{Fresh state properties}

\subsubsection{Flow/slump test}

This is the mean width of the spread of new solid utilizing a customary slump cone. It is utilized to gauge the consistency of cement. The standard (BS EN 12350-8) [23] was utilized to survey the flow-ability [24]. The cone was placed on the steel plate at $210 \mathrm{~mm}$ distance across checking. The concrete was put into the cone. The excess was removed within 30 seconds whilst moving it upward within 1-3 seconds. The time from lift to the $300 \mathrm{~mm}$ mark is noted. The biggest distance across is measured in two ways at $90^{\circ}$ to the closest $10 \mathrm{~mm}$. The normal from the point was taken to get the flow to the closest $10 \mathrm{~mm}$.

\subsubsection{V-funnel test}

The $\mathrm{V}$ funnel test was used to evaluate the ability of the concrete to fill the form in its weight. A moist towel was used to wet the inner surface of the $\mathrm{V}$-funnel. The opening of the V-funnel was cleaned and kept horizontal. The concrete was placed in the funnel and a straight edge plank was used to level the top. The gates were opened after 10 seconds and a stopwatch was started immediately. Once a visible space was observed through the funnel opening, the time was stopped and reading recorded.

\subsubsection{L-Box test}

The L-Box test was used to determine the ability of SCC to move through small checks with no separation or holding. The container was filled and left to stand for 60 \pm 10 seconds. The entryway was opened and monitored until flow stopped. The passing 
capacity proportion (PL) was computed by the ratio of the profundity of the level (H2) and the vertical profundity (H1).

\subsection{Hardened state properties}

\subsubsection{Determination of compressive strength}

Compressive strength of the hardened concrete was determined after curing period of 7 , 14 , and 21 days. Compressive strength of the developed SCC was determined according to ASTM C39 [25] by means of a compression testing machine (Model YES-2000, England) shown in Figure 1. The dimension of the cube was $150 \mathrm{~mm}$ in length, breadth and height. The sample was placed on the machine in proper order. Care was taken to ensure the idle was on the base plate. The load was increased at $140 \mathrm{~kg} / \mathrm{cm}^{2}$ until failure. The highest load was observed and recorded.

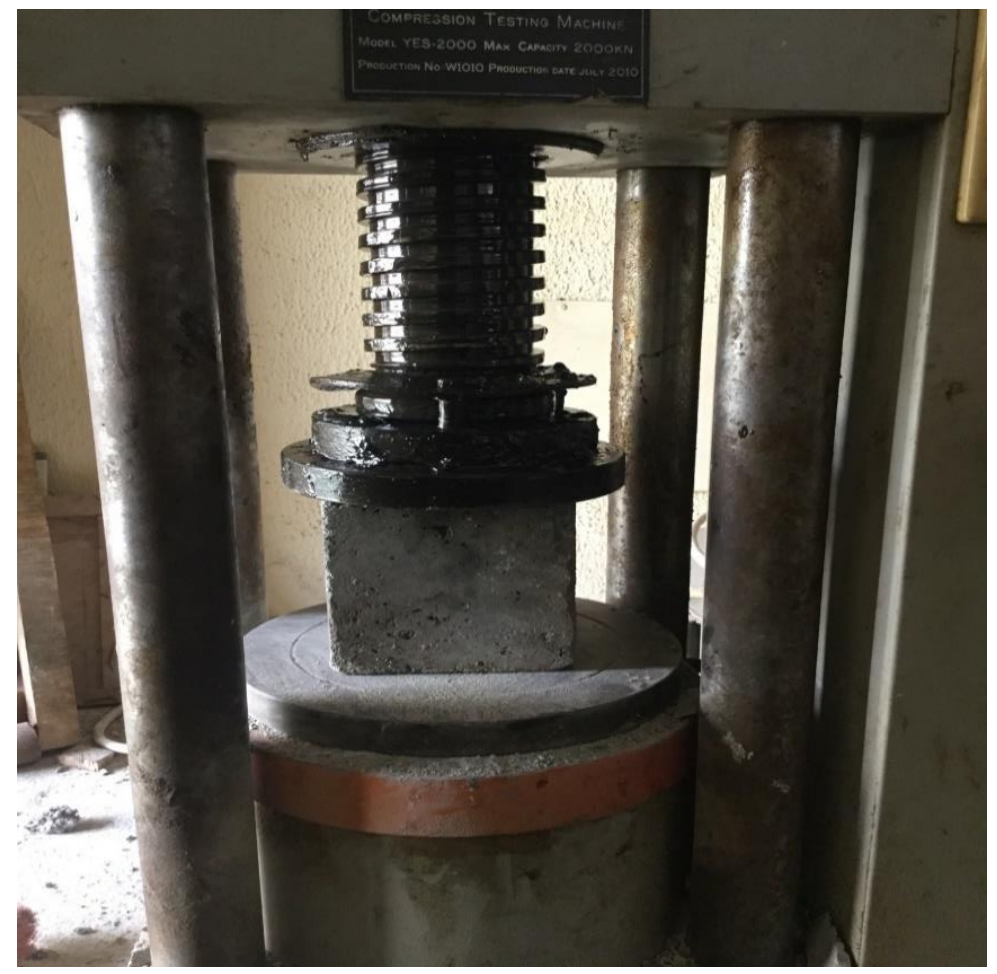

Fig. 1 Test sample in the compression testing machine

\subsubsection{Determination of flexural strength}

Flexural strength of the hardened concrete was determined after curing period of 7, 14 and 21 days. Flexural strength of the developed SCC was determined according to ASTM standards $[25,26]$ by means of a three-point bending test (Impact engineering, Australia) shown in Figure $2.100 \mathrm{~mm}$ by $450 \mathrm{~mm}$ samples were used for this test. The test ought to be dome on the sample following removal from the storage conditions in order to avoid surface drying which decreases flexural quality. The sample was placed on the stacking focuses. The hand completed surface of the example ought not to be in contact with stacking focuses. This will guarantee a worthy contact between the example and stacking focuses. The stacking framework was centered in connection to the connected power. 
Employing $0.10 \mathrm{~mm}$ and $0.38 \mathrm{~mm}$ leaf-type sensor gauges, care was to taken to avoid spaces between the samples. Any hole more than $0.10 \mathrm{~mm}$ was eliminated utilizing calfskin shims (6.4 $\mathrm{mm}$ thick and 25 to $50 \mathrm{~mm}$ long). Capping or pounding were considered to evacuate holes in abundance of $0.38 \mathrm{~mm}$. The sample was loaded consistently without stun till failure was achieved. Indian standard determined stacking rate of $400 \mathrm{~kg} / \mathrm{min}$ for $150 \mathrm{~mm}$ sample and $180 \mathrm{~kg} / \mathrm{min}$ for $100 \mathrm{~mm}$ sample was used at a stress increment rate $0.06 \pm 0.04 \mathrm{~N} / \mathrm{mm}^{2} . \mathrm{s}$ as per British standard.

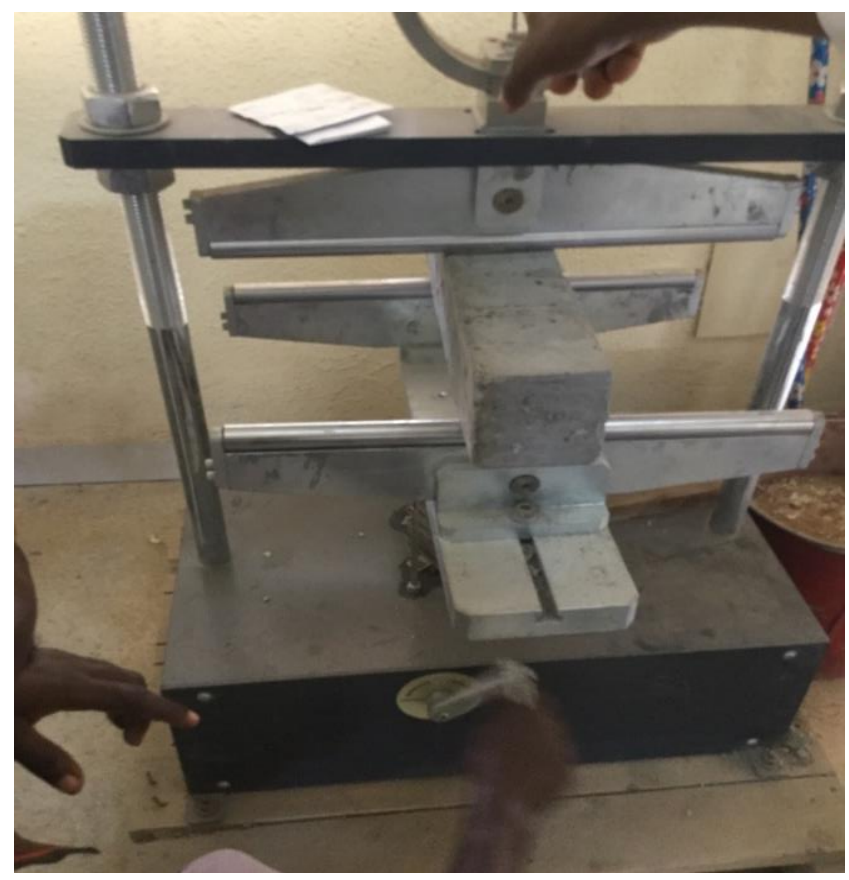

Fig. 2 Three-point bending test

\subsubsection{Water absorption test}

The value of the water absorption capacity of the hardened SSC sample was evaluated in percentage (\%) by weight (ASTM C642 standard) [27] . Each cube was immersed in water for 30 mins, 1 day, 2 days and 4 days. The surface was cleaned properly before weighing. The moisture absorption was calculated using the expression in Eqn. 1. Where $W i$ is the dry weight of the sample $(\mathrm{g})$ and $W t$ is the weight of the sample $(\mathrm{g})$ at particular time interval $(\mathrm{t})$.

Water absorbed $(w t \%)=\frac{W t-W i}{W i} \times 100$

\subsubsection{Microstructural characterization}

The microstructural analysis show the composition of the hardened sample was investigated using Scanning Electron Microscope with Energy Dispersive Spectroscopy (SEM-EDS). The SEM-EDS (SEM, Phenom proX, Phenom-World BV, The Netherlands) was used at microspore acceleration voltage of $15 \mathrm{kV}$ and magnification of $\times 1500$ Adeniyi, Ighalo [28]. 


\section{Results and Discussion}

\subsection{Fresh state properties}

In this section, the fresh state properties of SCC obtained using silica fume as partial cement replacement was discussed. The tests considered were the flow test, V-funnel test and the L-box test. The results of the flow test are shown in Table 3. It can be observed that that partial cement replacement with silica fume improved the flow properties of the SCC. The flow properties were increased by a factor of about 6.64 with 35 vol\% partial replacement of cement in the SCC. The results of the V-funnel test are shown in Table 4. The positive effect of silica fume partial replacement on the flow-ability in SCC is also emphasized from these results as less time is required before a visible space was observed through the funnel opening. The time decreased from 7 seconds to 4.3 seconds with 35 vol\% partial cement replacement. The results of the L-box test are shown in Table 5. It can be observed from the results of the study that ability of SCC to move through small checks with no separation or holding was improved by partial replacement (except for 25 vol\%). Rantung, Supit [2] observed that the flow properties of SSC were improved when fly ash was used as partial cement replacement which is in agreement with the observations of this study. Similar observations were also made by Ardalan, Joshaghani [6] for pumice, fly ash and slag as partial cement replacement.

Table 3. Results for flow test

\begin{tabular}{ccc}
\hline Extent of cement replacement (vol \%) & Flow $(\mathrm{mm})$ & $\mathrm{T}_{50}(\mathrm{Sec})$ \\
\hline 0 & 70 & 4.00 \\
15 & 400 & 4.30 \\
25 & 450 & 4.08 \\
35 & 465 & 4.00 \\
\hline
\end{tabular}

Table 4. Results for V-funnel test

\begin{tabular}{cc}
\hline Extent of cement replacement (vol \%) & $\mathrm{T}(\mathrm{Sec})$ \\
\hline 0 & 7.00 \\
15 & 6.00 \\
25 & 5.00 \\
35 & 4.30 \\
\hline
\end{tabular}

Table 5. Results for L-box test

\begin{tabular}{cc}
\hline Extent of cement replacement (vol \%) & $\mathrm{H} 2 / \mathrm{H} 1$ \\
\hline 0 & 0.22 \\
15 & 0.42 \\
25 & 0.20 \\
35 & 0.44 \\
\hline
\end{tabular}

\subsection{Hardened state properties}

In this section, the mechanical, microstructural and compositional properties of the developed SCC was discussed.

\subsubsection{Compressive strength}

The results of the compressive strength are shown in Table 6. It can be observed that partial replacement of cement with silica fume reduced the compressive strength of the SSC over the entire domain of the curing time. Higher partial replacement led to 
lesser compressive strength. It was also observed that curing improved the compressive strength with time (with an optimum obtained at 21 days curing time). This is because the partial replacement material was not able to improve the void filing ability of the composite concrete [21]. Further reasons for the decrease in compressive strength with partial cement replacement of silica fumes is due to weak interfacial transition zone, the porosity of the mortar during adhesion to the fine and coarse aggregates and the formation of cracks in the aggregates [29, 30]. Others studies have made similar observations to those noticed in this investigation. Sasanipour, Aslani [20] also observed a decrease in compressive strength in SSC with silica fumes partial cement replacement. Rantung, Supit [2] observed a decrease in compressive strength in SSC with fly ash partial cement replacement. Similar observations was also made by Ofuyatan and Edeki [31], Ranjbar, Behnia [16] and Ofuyatan and Edeki [32] for SSC with palm oil fuel ash partial cement replacement and by Raisi, Amiri [15] for rice husk ash partial cement replacement.

Table 6. Results for compressive strength

\begin{tabular}{cccc}
\hline $\begin{array}{c}\text { Extent of cement } \\
\text { replacement (vol \%) }\end{array}$ & 7 Days $\left(\mathrm{kN} / \mathrm{mm}^{2}\right)$ & $\begin{array}{c}14 \text { Days } \\
\left(\mathrm{kN} / \mathrm{mm}^{2}\right)\end{array}$ & $\begin{array}{c}21 \text { Days } \\
\left(\mathrm{kN} / \mathrm{mm}^{2}\right)\end{array}$ \\
\hline 0 & 19.70 & 30.70 & 39.24 \\
15 & 20.30 & 27.80 & 34.42 \\
25 & 13.30 & 20.50 & 25.10 \\
35 & 9.50 & 16.10 & 20.60 \\
\hline
\end{tabular}

\subsubsection{Flexural strength}

The results of the flexural strength are shown in Table 7. It can be observed that partial replacement of cement with silica fume reduced the flexural strength of the SCC over the entire domain of the curing time. This is due to the poor structure of SCC with partial replacement leading to stress concentration and the weakening of the interfacial bond between mortar and aggregates [16]. Ranjbar, Behnia [16] observed a decrease in flexural strength in SCC with palm oil fuel ash partial cement replacement which is in agreement with the observations of this study.

Table 7. Results for flexural strength

\begin{tabular}{cccc}
\hline $\begin{array}{c}\text { Extent of cement } \\
\text { replacement (vol \%) }\end{array}$ & 7 Days $\left(\mathrm{kN} / \mathrm{mm}^{2}\right)$ & $\begin{array}{c}14 \text { Days } \\
\left(\mathrm{kN} / \mathrm{mm}^{2}\right)\end{array}$ & $\begin{array}{c}21 \text { Days } \\
\left(\mathrm{kN} / \mathrm{mm}^{2}\right)\end{array}$ \\
\hline 15 & 4.6 & 2.5 & 5.0 \\
25 & 2.0 & 1.0 & 2.0 \\
35 & 1.0 & 3.0 & 1.5 \\
\hline
\end{tabular}

\subsubsection{Water absorption}

The results of the water absorption of the hardened SCC are shown in Table 7. Partial cement replacement with $35 \mathrm{vol} \%$ silica fumes led to the highest water absorption. A rapid water absorption was observed after the first day of the concrete preparation which gradually tailed off with time. Water absorption in concrete is increased due to the presence of porous structures [33, 34]. A high partial replacement leading to more water absorption has been observed in other studies. Sasanipour, Aslani [20] and Xuan, Zhan [35] made similar observations whilst using recycled aggregates. 
Table 8. Results for water absorption

\begin{tabular}{ccccc}
\hline $\begin{array}{c}\text { Extent of cement } \\
\text { replacement (vol \%) }\end{array}$ & $\begin{array}{c}\text { 4 days } \\
\text { (wt \%) }\end{array}$ & $\begin{array}{c}2 \text { days } \\
\text { (wt \%) }\end{array}$ & $\begin{array}{c}1 \text { day } \\
\text { (wt \%) }\end{array}$ & $\begin{array}{c}30 \text { minutes } \\
\text { (wt \%) }\end{array}$ \\
\hline $15 \%$ & 2.2 & 1.5 & 1.8 & 0.0 \\
$25 \%$ & 1.4 & 2.8 & 0.2 & 0.0 \\
$35 \%$ & 3.0 & 3.9 & 7.9 & 0.0 \\
\hline
\end{tabular}

\subsubsection{Microstructural analysis}

SEM micrographs of the hardened SSC at 15 vol\% (a), 25 vol\% (b) and 35 vol\% (c) partial replacement are shown in Figure 3. On the surface of the sample with $15 \mathrm{vol} \%$ partial cement replacement, micro-clusters can be observed but there are no deep voids on the surface. On the surface of the sample with $25 \mathrm{vol} \%$ partial cement replacement, bigger micro-clusters (lumps) can be observed and there is the presence of some deep voids after curing. These lumps are as a result of the coarse aggregate composition of the concrete. For the surface of the sample with $35 \mathrm{vol} \%$ partial cement replacement, there are no observable lumps or micro-clusters on the concrete but a deep void can be observed. Voids are formed when the irregular shape of the coarse aggregate combines with a poor interfacial effect with the cementitious material and lead to interstitials during curing.
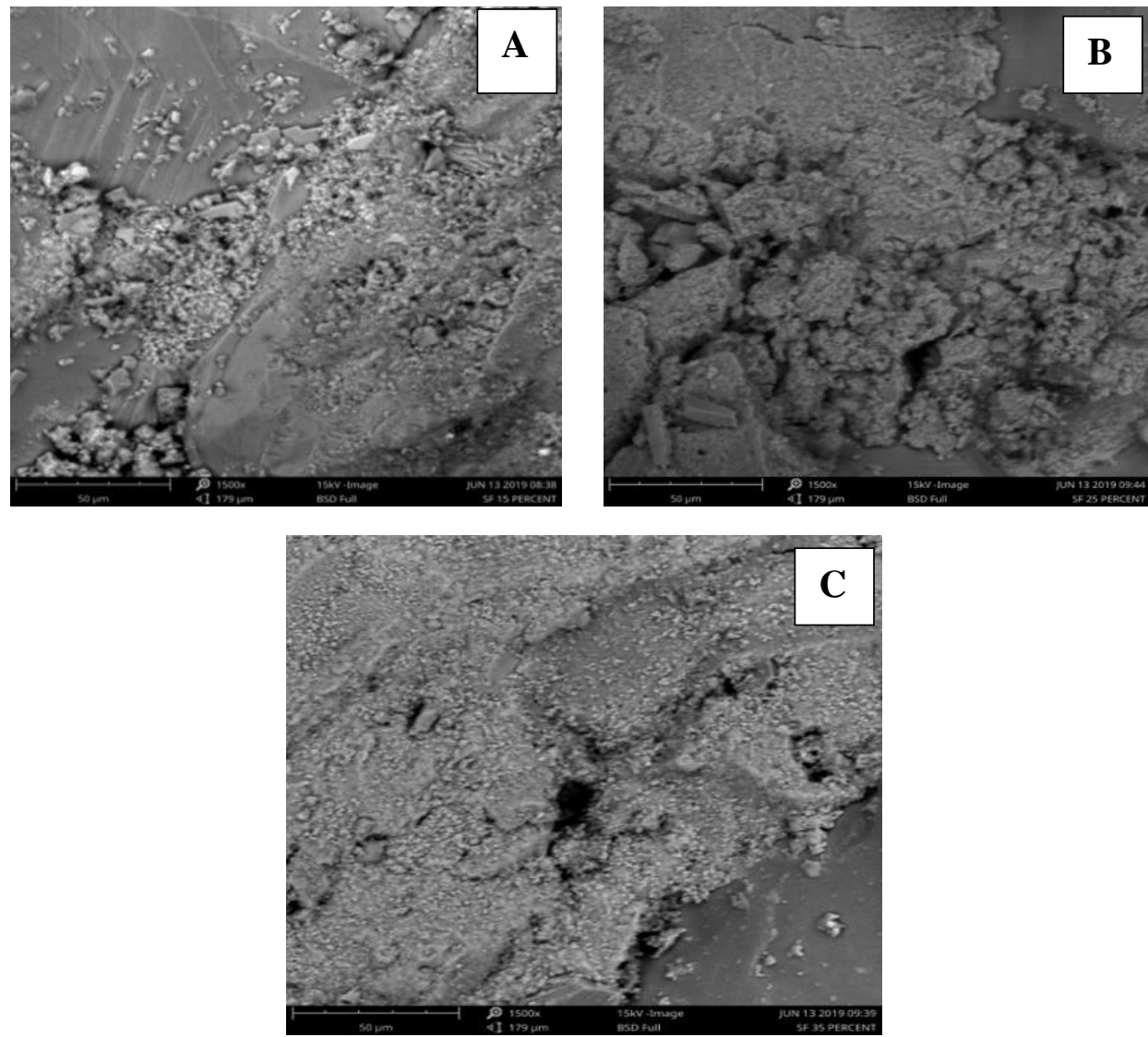

Fig. 3 SEM of the SSC at 15 vol\% (a), 25 vol\% (b) and 35 vol\% (c) partial replacement $(\times 1500$ magnification $)$ 


\subsubsection{SSC composition}

The summary of the SSC composition is given in Table 9 and the associated EDS spectrum is given in Figure 4. The results are presented with the exception of oxygen and hydrogen. The major constituent of the SSC with partial replacement is carbon, calcium and silicon. The silicon content is due to the presence of $\mathrm{SiO}_{2}$ in the coarse and fine aggregates. Furthermore, silica fume partial replacement is also a major contributor to the silica content of the SSC. There is no observable variation/relationship between SSC composition and increasing partial replacement. Calcium is a major constituent of cement (from lime and gypsum) hence it large presence in the SSC. The high carbon content is due to the high amount of soot in the silica fume. The iron and aluminum form oxides which are also major constituents in the cement hence their large amount in the concrete. The trace elements (most of which are earth and rare earth metals) in the concrete is due to the impurities in the cement and the other constituents within the crystalline structure of the coarse and fine aggregates. These trace elements usually exist as oxides [36]. Though this composition is good for comparison it is in itself no holistic due to it being on an oxygen and hydrogen free basis.

Table 9. Summary SSC composition

\begin{tabular}{cccc}
\hline Element & $\begin{array}{c}\text { Weight Conc. } \\
(15 \text { vol \%) }\end{array}$ & $\begin{array}{c}\text { Weight Conc. } \\
(25 \text { vol \% })\end{array}$ & $\begin{array}{c}\text { Weight Conc. } \\
(35 \text { vol \%) }\end{array}$ \\
\hline $\mathrm{C}$ & 29.88 & 23.14 & 32.98 \\
$\mathrm{Ca}$ & 29.44 & 31.89 & 31.42 \\
$\mathrm{Si}$ & 23.91 & 16.81 & 17.62 \\
$\mathrm{~N}$ & - & 17.47 & 10.76 \\
$\mathrm{Al}$ & 9.12 & 2.08 & 2.35 \\
$\mathrm{Na}$ & 3.25 & 0.81 & 1.07 \\
$\mathrm{Zr}$ & 2.26 & - & 1.26 \\
$\mathrm{Fe}$ & 1.88 & 3.10 & 0.97 \\
$\mathrm{Zn}$ & - & 1.56 & - \\
$\mathrm{S}$ & - & 1.25 & 0.67 \\
$\mathrm{Ti}$ & 0.25 & - & 0.20 \\
$\mathrm{Mg}$ & - & 0.97 & 0.70 \\
$\mathrm{P}$ & - & 0.93 & - \\
\hline
\end{tabular}



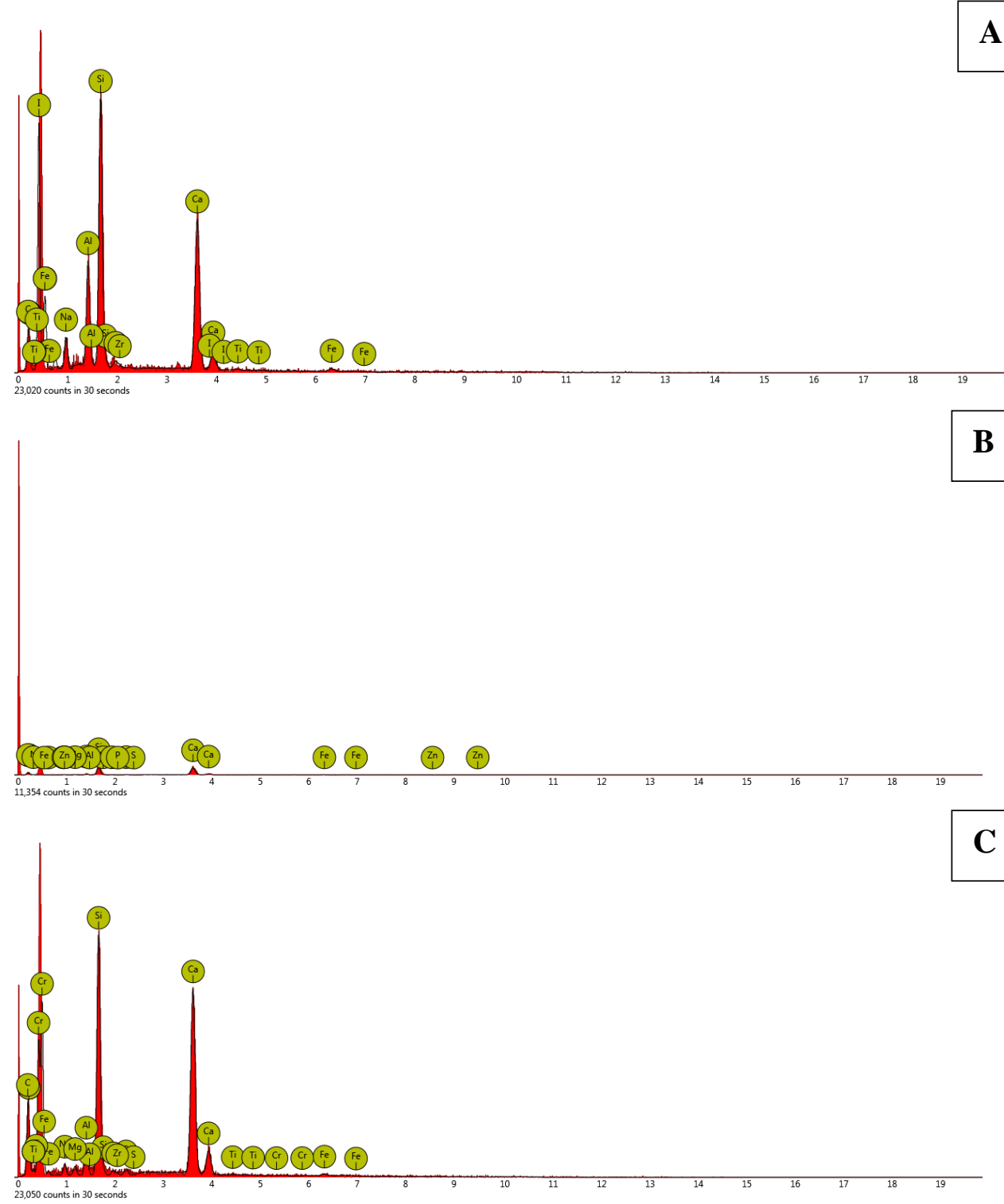

B

Fig. 4. EDS spectra for the SSC at 15 vol\% (a), 25 vol\% (b) and 35 vol\% (c) partial replacement

\section{Conclusion}

In this study, fresh and hardened properties of self-compacting concrete obtained using silica fumes as partial replacement for cement was successfully evaluated for arrays of properties applicable to concrete development. Several key conclusions were drawn from the study.

Based on the results of the study, it is obtained that the utilization of silica fume as partial cement replacement gave a traceable improvement over the fresh state properties of the concrete in the domain of the flow-ability. This is confirmation of its usability in place of 
cement in building industry. At the same time, the flow properties of SSC were improved when fly ash was used as partial cement replacement.

On the mechanical energy consideration, it is confirmed that the higher partial replacement led to lesser compressive strength due to weak interfacial transition zone. Partial replacement of cement with silica fume reduced the flexural strength of the SSC over the entire domain of the curing time. The decrease in compressive strength with partial cement replacement of silica fumes is due to weak interfacial transition zone. The weak transition zone associated with the silica fume application is negatively impacting the mechanical properties on curing. Moreover, the porosity of the mortar during adhesion to the fine and coarse aggregates and the formation of cracks in the aggregates are equally controllable.

Furthermore, it is equally deduced that the porosity of the mortar during adhesion to the fine and coarse aggregates. Voids were found formed when the irregular shape of the coarse aggregate combines with a poor interfacial effect with the cementitious material and lead to interstitials during curing. A high partial replacement leads to more water absorption. Moreover, the rapid water absorption was observed after the first day of the concrete preparation which gradually tailed off with time.

There is no observable variation/relationship between SSC composition and increasing partial replacement.

\section{References}

[1] Aslani F, Ma G, Wan DLY, Muselin G. Development of high-performance selfcompacting concrete using waste recycled concrete aggregates and rubber granules. Journal of Cleaner Production. 2018;182:553-66. https://doi.org/10.1016/i.jclepro.2018.02.074

[2] Rantung D, Supit SW, Nicolaas S. Effects of different size of fly ash as cement replacement on self-compacting concrete properties. Journal of Sustainable Engineering: $\quad$ Proceedings $\quad$ Series. 2019;1:180-6. https://doi.org/10.35793/joseps.v1i2.25

[3] Brouwers H, Radix H. Self-compacting concrete: theoretical and experimental study. Cement and Concrete Research. 2005;35:2116-36. https://doi.org/10.1016/i.cemconres.2005.06.002

[4] Okamura H, Ouchi M. Self-compacting concrete. Journal of advanced concrete technology. 2003;1:5-15. https://doi.org/10.3151/jact.1.5

[5] Ofuyatan 0, Olowofoyeku A, Edeki S, Oluwafemi J, Ajao A, David O. Incorporation of Silica Fume and Metakaolin on Self Compacting Concrete. Journal of Physics: Conference Series: IOP Publishing; 2019. p. 042089. https://doi.org/10.1088/17426596/1378/4/042089

[6] Ardalan RB, Joshaghani A, Hooton RD. Workability retention and compressive strength of self-compacting concrete incorporating pumice powder and silica fume. Construction and Building Materials. 2017;134:116-22. https://doi.org/10.1016/j.conbuildmat.2016.12.090

[7] Manzi S, Mazzotti C, Bignozzi MC. Self-compacting concrete with recycled concrete aggregate: Study of the long-term properties. Construction and Building Materials. 2017;157:582-90. https://doi.org/10.1016/i.conbuildmat.2017.09.129

[8] Mastali M, Dalvand A. Use of silica fume and recycled steel fibers in self-compacting concrete (SCC). Construction and Building Materials. 2016;125:196-209. https://doi.org/10.1016/j.conbuildmat.2016.08.046 
[9] Arachchige US, amakm A, Balasuriya B, Chathumini K, Dassanayake N, Devasurendra J. Environmental Pollution by Cement Industry. International Journal of Research. $2019 ; 6$.

[10] Dewald U, Achternbosch M. Why more sustainable cements failed so far? Disruptive innovations and their barriers in a basic industry. Environmental Innovation and Societal Transitions. 2016;19:15-30. https://doi.org/10.1016/j.eist.2015.10.001

[11] Bernal J, Reyes E, Massana J, León N, Sánchez E. Fresh and mechanical behavior of a self-compacting concrete with additions of nano-silica, silica fume and ternary mixtures. Construction and building materials. 2018;160:196-210. https://doi.org/10.1016/i.conbuildmat.2017.11.048

[12] Mastali M, Dalvand A. The impact resistance and mechanical properties of fiber reinforced self-compacting concrete (SCC) containing nano-SiO2 and silica fume. European Journal of Environmental and Civil Engineering. 2018;22:1-27. https://doi.org/10.1080/19648189.2016.1177604

[13] Guo Z, Jiang T, Zhang J, Kong X, Chen C, Lehman DE. Mechanical and durability properties of sustainable self-compacting concrete with recycled concrete aggregate and fly ash, slag and silica fume. Construction and Building Materials. 2020;231:117115. https://doi.org/10.1016/i.conbuildmat.2019.117115

[14] Ghoddousi P, Saadabadi LA. Study on hydration products by electrical resistivity for self-compacting concrete with silica fume and metakaolin. Construction and Building Materials. 2017;154:219-28. https://doi.org/10.1016/j.conbuildmat.2017.07.178

[15] Raisi EM, Amiri JV, Davoodi MR. Mechanical performance of self-compacting concrete incorporating rice husk ash. Construction and Building Materials. 2018;177:148-57. https://doi.org/10.1016/j.conbuildmat.2018.05.053

[16] Ranjbar N, Behnia A, Alsubari B, Birgani PM, Jumaat MZ. Durability and mechanical properties of self-compacting concrete incorporating palm oil fuel ash. Journal of Cleaner Production. 2016;112:723-30. https://doi.org/10.1016/i.jclepro.2015.07.033

[17] Khan MI, Siddique R. Utilization of silica fume in concrete: Review of durability properties. Resources, Conservation and Recycling. 2011;57:30-5. https://doi.org/10.1016/j.resconrec.2011.09.016

[18] Bubshait AA, Tahir BM, Jannadi M. Use of microsilica in concrete construction: Reviews state-of-the-art silica fume concrete and discusses the influence silica fume has on the various properties of concrete and the effect on the bond between parent concrete and new concrete. Building research and information. 1996;24:41-9. https://doi.org/10.1080/09613219608727497

[19] Leung HY, Kim J, Nadeem A, Jaganathan J, Anwar M. Sorptivity of self-compacting concrete containing fly ash and silica fume. Construction and Building Materials. 2016;113:369-75. https://doi.org/10.1016/i.conbuildmat.2016.03.071

[20] Sasanipour H, Aslani F, Taherinezhad J. Effect of silica fume on durability of selfcompacting concrete made with waste recycled concrete aggregates. Construction and Building Materials. 2019;227:116598. https://doi.org/10.1016/j.conbuildmat.2019.07.324

[21] Zarnaghi VN, Fouroghi-Asl A, Nourani V, Ma H. On the pore structures of lightweight self-compacting concrete containing silica fume. Construction and Building Materials. 2018;193:557-64. https://doi.org/10.1016/j.conbuildmat.2018.09.080

[22] EFNARC S. Guidelines for self-compacting concrete. London, UK: Association House. 2002;32:34.

[23] EN B. 12350-8: 2010. Testing fresh concrete.

[24] EN 12350-8 B. 12350-8. Testing fresh concrete. 2010.

[25] Standard A. Standard test method for compressive strength of cylindrical concrete specimens. ASTM C39. 2010. 
[26] ASTM. ASTM C1602/C1602M-12: Standard specific cation for mixing water used in the production of hydraulic cement concrete. ASTM International West Conshohocken, PA, USA; 2012.

[27] C642-13 A. Standard test method for density, absorption, and voids in hardened concrete. West Conshohocken, PA: ASTM International. 2013.

[28] Adeniyi AG, Ighalo JO, Onifade DV. Biochar from the Thermochemical Conversion of Orange (Citrus sinensis) Peel and Albedo: Product Quality and Potential Applications. Chemistry Africa. 2020. https://doi.org/10.1007/s42250-020-00119-6

[29] Grdic ZJ, Toplicic-Curcic GA, Despotovic IM, Ristic NS. Properties of self-compacting concrete prepared with coarse recycled concrete aggregate. Construction and Building Materials. 2010;24:1129-33. https://doi.org/10.1016/i.conbuildmat.2009.12.029

[30] Silva YF, Robayo RA, Mattey PE, Delvasto S. Properties of self-compacting concrete on fresh and hardened with residue of masonry and recycled concrete. Construction and Building Materials. 2016;124:639-44. https://doi.org/10.1016/i.conbuildmat.2016.07.057

[31] Ofuyatan 0, Edeki S. Dataset on the durability behavior of palm oil fuel ash self compacting concrete. Data in brief. 2018;19:853-8. https://doi.org/10.1016/i.dib.2018.05.121

[32] Ofuyatan 0, Edeki S. Dataset on predictive compressive strength model for selfcompacting concrete. Data in brief. 2018;17:801-6. https://doi.org/10.1016/i.dib.2018.02.008

[33] Khoshkenari AG, Shafigh P, Moghimi M, Mahmud HB. The role of 0-2 mm fine recycled concrete aggregate on the compressive and splitting tensile strengths of recycled concrete aggregate concrete. Materials \& Design. 2014;64:345-54. https://doi.org/10.1016/i.matdes.2014.07.048

[34] Modani PO, Mohitkar VM. Self-compacting concrete with recycled aggregate: A solution for sustainable development. International Journal of Civil \& Structural Engineering. 2014;4:430-40.

[35] Xuan D, Zhan B, Poon CS. Durability of recycled aggregate concrete prepared with carbonated recycled concrete aggregates. Cement and Concrete Composites. 2017;84:214-21. https://doi.org/10.1016/i.cemconcomp.2017.09.015

[36] Limbachiya M, Marrocchino E, Koulouris A. Chemical-mineralogical characterisation of coarse recycled concrete aggregate. Waste Management. 2007;27:201-8. https://doi.org/10.1016/i.wasman.2006.01.00 